\title{
Staying cool or staying safe in a human-dominated landscape: which is more relevant for brown bears?
}

\author{
Andrés Ordiz ${ }^{1}$ (D) Ole-Gunnar Støen ${ }^{1,2} \cdot$ Miguel Delibes $^{3} \cdot$ Jon E. Swenson $^{1,2}$
}

Received: 2 June 2016 / Accepted: 31 August 2017 / Published online: 8 September 2017

(C) The Author(s) 2017. This article is an open access publication

\begin{abstract}
Pigeon et al. (2016) Staying cool in a changing landscape: the influence of maximum daily ambient temperature on grizzly bear habitat selection. Oecologia 181:1101. doi:10.1007/s00442-016-3630-5 analyzed the effect of ambient temperature on the habitat selection of grizzly bears (Ursus arctos) in Alberta, Canada. They concluded that temperature played a significant role in bear habitat selection and that it was unlikely that human activity introduced biases to the habitat selection of bears. However, Pigeon et al. did not consider variables related to human activities in their analyses. They also misinterpreted previous research that has accounted for temperature in the habitat selection of brown bears. There is much literature published on the negative effects of human disturbance on wildlife in general and on bears in particular. Downplaying the role of human disturbance could have important negative consequences if, in fact, human disturbance were a more important factor than thermoregulation. Indeed, dismissing the importance of human influence, in the face of contradictory evidence, could tempt managers to disregard an important factor that is difficult and often unpopular to deal with in their conservation plans.
\end{abstract}

Communicated by Andreas Zedrosser.

Andrés Ordiz

andres.ordiz@gmail.com

1 Faculty of Environmental Sciences and Natural Resource Management, Norwegian University of Life Sciences, Postbox 5003, NO-1432 Ås, Norway

2 Norwegian Institute for Nature Research, NO-7485 Trondheim, Norway

3 Department of Conservation Biology, Estación Biológica de Doñana, Consejo Superior de Investigaciones Científicas, E-41092 Seville, Spain
Keywords Bears · Conservation · Human disturbance · Management $\cdot$ Warming climate

It is well documented that human disturbance can affect the behavior and habitat use of wildlife (e.g., Harrington and Veitch 1992; Beale and Monaghan 2004; Müllner et al. 2004; Blanc et al. 2006; Moore and Seigel 2006; Tuomainen and Candolin 2011). Thus, management efforts to conserve threatened or endangered species often involve managing or restricting human activities (e.g., Mattson et al. 1996; Richardson and Miller 1997; Williams et al. 2013; Trouwborst 2015; Sutherland et al. 2015), which is often not popular among the affected people (Woodroffe et al. 2005; Redpath et al. 2013 for reviews on a variety of conservation conflicts).

Pigeon et al. (2016) analyzed the effect of ambient temperature on the habitat selection of grizzly bears (i.e., brown bears Ursus arctos) in a landscape with a heavy human footprint in Alberta, Canada. They acknowledged that bear habitat selection is mainly driven by food, intra-specific factors (sex and reproductive status), and avoidance of human activity, but concluded that temperature played a significant role in bear habitat selection and argued that in a changing climate, large mammals may increasingly need to adjust spatial and temporal selection patterns in response to thermal constraints. Although they did not consider variables related to human activities, they also concluded that it was unlikely that human activity introduced temporal, spatial, or sex-related biases to the habitat selection patterns that they observed for male and female grizzly bears.

We feel that it is important to reexamine the role of human disturbance in affecting the behavior and habitat use by brown bears. Pigeon et al. did cite studies carried out in Alberta that show that human development, activities, 
and human-caused mortality influence bear habitat selection (Gibeau et al. 2002; Nielsen et al. 2004, 2010). Generally, human disturbance has been documented to be a major factor influencing brown bear habitat selection across the widespread range of the species in the Holartic (Naves et al. 2003; Rode et al. 2006; Nellemann et al. 2007, among many others). It is important to examine the conclusions of Pigeon et al. because it would make the conservation of threatened and endangered bear populations much easier if factors other than human disturbance were most important in influencing the bears' habitat use. Of course, downplaying the role of human disturbance could have important negative consequences if, in fact, human disturbance were a more important factor than thermoregulation.

Pigeon et al. (2016) measured temperature across habitat types and took into account foraging requirements of bears, sex, time of the day, and three periods during summer to control for daily and seasonal variation in bear activity. However, we see as a major weakness of their study that they did not include any variable to evaluate the effect of human activities or related infrastructures among the predictors that may explain bear habitat selection.

In support of their conclusions, Pigeon et al. stated that there are no studies specifically linking temperature to habitat selection patterns for terrestrial bear species. However, they cited McLellan and McLellan (2015), who actually documented that when bears were foraging on berries in an open landscape, there was no relation between daily maximum temperature (from 20.4 to $40.1{ }^{\circ} \mathrm{C}$ ) and the total amount of time that the bears were active. In addition, McLellan and McLellan found no difference in bear activity levels during day or night between warm $\left(20.4-27.3{ }^{\circ} \mathrm{C}\right)$ and hot $\left(27.9-40.1^{\circ} \mathrm{C}\right.$ ) days. Therefore, McLellan and McLellan concluded that food acquisition had a stronger influence on activity levels of grizzly bears than heat dissipation. We also accounted for ambient temperature in our paper on the selection of resting sites by brown bears in Sweden (Ordiz et al. 2011, also published in Oecologia). Pigeon et al. cited this paper and correctly summarized our major findings, that human activity was the most important factor we examined in influencing the use of resting sites by brown bears. However, Pigeon et al. wrongly stated that we did not consider the potential for temperature-mediated selection of denser cover during daytime and suggested that "thermoregulatory needs could have played a role in the selection for dense cover observed by Ordiz et al. (2011)".

We did acknowledge that temperature might influence the selection of bed sites and, therefore, installed temperature loggers at six permanent sites in the main habitat types present in our study area. Temperature and daylight length were highly correlated ( $r=0.87$ ), thus we included only daylight length in the final selection process because it was a more explanatory variable in our analyses; a candidate model with temperature instead of daylight length and all other variables being equal, had an AIC larger (546.6) than the model with daylight length (540.9). Furthermore, daylight length was a relevant variable to include because bear hunting is allowed only during the day. In our study, daylight length, a surrogate of both temperature and the time of the day when hunting occurred, and the human-associated variables (distance to human settlements and day/night) influenced bear selection of cover at beds the most. Bears selected denser habitats, not just denser cover, at bed sites when human activity was more intense and dispersed.

Most importantly, our conclusion that human disturbance was more important than thermoregulation has been corroborated in recent years by studies showing that human activities affect brown bear behavior and demography at different scales in Scandinavia, where bear mortality is mostly human caused (Bischof et al. 2009; Steyaert et al. 2016). Human activities affect bear habitat selection at different temporal and spatial scales (Moe et al. 2007; Nellemann et al. 2007; Martin et al. 2010), and bears become less diurnal after bear hunting seasons start (Ordiz et al. 2012) and where road density is higher (Ordiz et al. 2014, 2017). The conclusion that bears seek concealment cover to avoid humans (Ordiz et al. 2011) is further supported by the finding that, after experimental approaches to collared bears, they move to places even more concealed (Salhén et al. 2015). Wolves have shown the same result after approaches (Wam and Hjeljord 2012). After encounters with people, bears were also less active during daytime and more active during nighttime for a number of days (Ordiz et al. 2013).

As Pigeon et al. (2016) noted in their introduction, thermoregulatory needs are important for wildlife in general and it is intuitive to expect that temperature can also play a role in bear habitat selection. Nevertheless, there is nowadays a quite convincing bulk of literature documenting the effects of human activities on wildlife in general (e.g., Boyle and Samson 1985; Frid and Dill 2002; Blanc et al. 2006 for non-consumptive effects of human activities), and bears in particular. Humans cause most mortality in virtually all large carnivore populations (Woodroffe and Ginsberg 1998; Treves 2009), including bears (e.g., Sánchez-Mercado et al. 2008; Bischof et al. 2009). Human activities cause habitat fragmentation and habitat loss for different bear species (Liu et al. 1999; Naves et al. 2003; Escobar et al. 2015; Puri et al. 2015; Andersen and Aars 2016). Bears perceive changes in the level of risk posed by human activities, which can trigger behavioral responses (e.g., Stillfried et al. 2015) and/or stress responses (Støen et al. 2015; Ditmer et al. 2015). Not surprisingly, human activities are a core issue when planning conservation actions, e.g., to increase landscape connectivity (Brodie et al. 2015) and to establish management areas to reduce disturbance to, and habituation by, bears (Coleman et al. 2013). 
Brown bears in Alberta are no exception, with many studies reporting severe effects of human activities on bear behavior and demography (e.g., Gibeau et al. 2002; Mueller et al. 2004; Munro et al. 2006; Nielsen et al. 2004, 2010; Ross 2002; COSEWIC 2012; Bourbonnais et al. 2013; Linke et al. 2013, among many others). For instance, present low bear densities and distribution in Alberta are associated with human disturbance (Linke et al. 2013), and $>80 \%$ of documented bear mortality is caused by people (Bourbonnais et al. 2013).

Whereas we do not cast doubt on the conclusion of Pigeon et al. (2016) that large mammals, including bears, may increasingly need to adjust spatial and temporal selection patterns in response to changing thermal constraints (but see McLellan and McLellan 2015), we suggest that human disturbance should have been taken into account quantitatively in their study. Otherwise, the statements on the lack of human influence on bear habitat selection are not supported by any data, and their results may have been different if human factors had been included. Our criticism of Pigeon et al.'s (2016) conclusion that human influence was not important for habitat selection of the threatened brown bear in Alberta is not trivial. Failing to include factors of human influence into their analysis and dismissing the importance of human influence, in the face of so much contradictory evidence, could tempt managers (in Canada and elsewhere) to disregard an important factor that is difficult and often unpopular to deal with in their conservation plans.

Acknowledgements We greatly acknowledge the support of Center for Advanced Study in Oslo, Norway that funded and hosted our research project ("Climate effects on harvested large mammal populations") during the academic year 2015/16. This is paper no. 241 from the Scandinavian Brown Bear Research Project.

Author contribution statement AO and JES conceived the manuscript. AO wrote the manuscript and JES, MD and OGS provided comments and editorial advice.

Open Access This article is distributed under the terms of the Creative Commons Attribution 4.0 International License (http://creativecommons.org/licenses/by/4.0/), which permits unrestricted use, distribution, and reproduction in any medium, provided you give appropriate credit to the original author(s) and the source, provide a link to the Creative Commons license, and indicate if changes were made.

\section{References}

Andersen M, Aars J (2016) Barents Sea polar bears (Ursus mariti$m u s)$ : population biology and anthropogenic threats. Polar Res 35(1):26029

Beale CM, Monaghan P (2004) Human disturbance: people as predation-free predators? J Appl Ecol 41:335-343

Bischof R, Swenson JE, Yoccoz NG, Mysterud A, Gimenez O (2009) The magnitude and selectivity of natural and multiple anthropogenic mortality causes in hunted brown bears. J Anim Ecol 78:656-665

Blanc R, Guillemain M, Mouronval J-B, Desmonts D, Fritz H (2006) Effects of non-consumptive leisure disturbance to wildlife. Rev Ecol (Terre Vie) 61:117-133

Bourbonnais ML, Nelson TA, Cattet MRL, Darimont CT, Stenhouse GB (2013) Spatial analysis of factors influencing long-term stress in the grizzly bear (Ursus arctos) population of Alberta, Canada. PLoS One 8(12):e83768. doi:10.1371/journal.pone.0083768

Boyle SA, Samson FB (1985) Effects of nonconsumptive recreation on wildlife: a review. Wildl Soc Bull 13:110-116

Brodie JF, Giordano AJ, Dickson BG, Hebblewhite M, Bernard H, Mohd-Azlan J, Anderson J, Ambu L (2015) Evaluating multispecies landscape connectivity in a threatened tropical mammal community. Conserv Biol 29:122-132

Coleman TH, Schwartz CC, Gunther KA, Creel S (2013) Grizzly bear and human interaction in Yellowstone National Park: an evaluation of bear management areas. J Wildl Manag 77:1311-1320

COSEWIC (2012) COSEWIC assessment and status report on the grizzly bear Ursus arctos in Canada. Committee on the Status of Endangered Wildlife in Canada, Ottawa

Ditmer MA, Vincent JB, Werden LK, Tanner JC, Laske TG, Iaizzo PA, Garshelis D, Fieberg JR (2015) Bears show a physiological but limited behavioral response to unmanned aerial vehicles. Curr Biol 25:1-6

Escobar LE, Naeem M, Qiao H (2015) Anthropogenic disturbance and habitat loss for the red-listed Asiatic black bear (Ursus thibetanus): using ecological niche modeling and nighttime light satellite imagery. Biol Conserv 191:400-407

Frid A, Dill LM (2002) Human-caused disturbance stimuli as a form of predation risk. Conserv Ecol 6, http://www.consecol.org/vol6/ iss $1 / \operatorname{art} 11$

Gibeau ML, Clevenger AP, Herrero S, Wierzchowski J (2002) Grizzly bear response to human development and activities in the Bow River Watershed, Alberta, Canada. Biol Conserv 103:227-236

Harrington FH, Veitch AM (1992) Calving success of woodland caribou exposed to low-level jet fighter overflights. Arctic 45:213-218

Linke J, McDermid GJ, Fortin M-J, Stenhouse G (2013) Relationships between grizzly bears and human disturbances in a rapidly changing multi-use forest landscape. Biol Conserv 166:54-63

Liu J, Ouyang Z, Taylor WW, Groop R, Zhang H (1999) A framework for evaluating the effects of human factors on wildlife habitat: the case of giant pandas. Conserv Biol 13:1360-1370

Martin J, Basille M, Van Moorter B, Kindberg J, Allainé D, Swenson JE (2010) Coping with human disturbance: spatial and temporal tactics of the brown bear (Ursus arctos). Can J Zool 88:875-883

Mattson DJ, Herrero S, Wright RG, Pease CM (1996) Science and management of Rocky Mountain grizzly bears. Conserv Biol 10:1619-1629

McLellan ML, McLellan B (2015) Effect of season and high ambient temperature on activity levels and patterns of grizzly bears (Ursus arctos). PLoS One 10:e0117734

Moe TF, Kindberg J, Jansson I, Swenson JE (2007) Importance of diel behaviour when studying habitat selection: examples from female Scandinavian brown bears (Ursus arctos). Can J Zool 85:518-525

Moore MJC, Seigel RA (2006) No place to nest or bask: effects of human disturbance on the nesting and basking habits of yellowblotched map turtles (Graptemys flavimaculata). Biol Conserv 130:386-393

Mueller C, Herrero S, Gibeau ML (2004) Distribution of subadult grizzly bears in relation to human development in the Bow River Watershed, Alberta. Ursus 15:35-47

Müllner A, Linsenmair KE, Wikelski M (2004) Exposure to ecotourism reduces survival and affects stress response in hoatzin chicks Opisthocomus hoatzin. Biol Conserv 118:549-558 
Munro RHM, Nielsen SE, Price MH, Stenhouse GB, Boyce MS (2006) Seasonal and diel patterns of grizzly bear diet and activity in westcentral Alberta. J Mammal 87:1112-1121

Naves J, Wiegand T, Revilla E, Delibes M (2003) Endangered species constrained by natural and human factors: the case of brown bears in northern Spain. Conserv Biol 17:1276-1289

Nellemann C, Støen O-G, Kindberg J, Swenson JE, Vistnes I, Ericsson G, Katajisto J, Kaltenborn BP, Martin J, Ordiz A (2007) Terrain use by an expanding brown bear population in relation to age, resorts and human settlements. Biol Conserv 138:157-165

Nielsen SE, Boyce MS, Stenhouse GB (2004) Grizzly bears and forestry. I. Selection of clearcuts by grizzly bears in west-central Alberta, Canada. For Ecol Manag 199:51-65

Nielsen SE, McDermid G, Stenhouse GB, Boyce MS (2010) Dynamic wildlife models: seasonal foods and mortality risk predict occupancy-abundance and habitat selection in grizzly bears. Biol Conserv 143:1623-1634

Ordiz A, Støen O-G, Delibes M, Swenson JE (2011) Predators or prey? Spatio-temporal discrimination of human-derived risk by brown bears. Oecologia 166:59-67

Ordiz A, Støen O-G, Sæbo S, Kindberg J, Swenson JE (2012) Do bears know they are being hunted? Biol Conserv 152:21-28

Ordiz A, Støen O-G, Sæbo S, Sahlén V, Pedersen BE, Kindberg J, Swenson JE (2013) Lasting behavioural responses of brown bears to experimental human encounters. J Appl Ecol 50:306-314

Ordiz A, Kindberg J, Sæbø S, Swenson JE, Støen O-G (2014) Brown bear circadian behavior reveals human environmental encroachment. Biol Conserv 173:1-9

Ordiz A, Sæbø S, Kindberg J, Swenson JE, Støen O-G (2017) Seasonality and human disturbance alter brown bear activity patterns; implications for circumpolar carnivore conservation? Anim Conserv 20:51-60

Pigeon KE, Cardinal E, Stenhouse GB, Côté S (2016) Staying cool in a changing landscape: the influence of maximum daily ambient temperature on grizzly bear habitat selection. Oecologia 181:1101. doi:10.1007/s00442-016-3630-5

Puri M, Srivathsa A, Karanth KK, Samba Kumar N, Karanth U (2015) Multiscale distribution models for conserving widespread species: the case of sloth bear Melursus ursinus in India. Divers Distrib 21:1087-1100

Redpath SM, Young J, Evely A, Adams WM, Sutherland WJ, Whitehouse A, Amar A, Lambert RA, Lineell JDC, Watt A, Gutiérrez RJ (2013) Understanding and managing conservation conflicts. Trends Ecol Evol 28:100-109

Richardson CT, Miller CK (1997) Recommendations for protecting raptors from human disturbance: a review. Wildl Soc Bull 25:634-638
Rode KD, Robbins CT, Farley SD (2006) Sexual dimorphism, reproductive strategy, and human activities determine resource use by brown bears. Ecology 87:2636-2646

Ross PI (2002) Update COSEWIC status report on the grizzly bear Ursus arctos in Canada. COSEWIC assessment and update status report on the grizzly bear Ursus arctos in Canada. Committee on the Status of Endangered Wildlife in Canada, Ottawa

Salhén V, Ordiz A, Swenson JE, Støen O-G (2015) Behavioural differences between single Scandinavian brown bears (Ursus arctos) and females with dependent young when experimentally approached by humans. PLoS One 10:e0121576

Sánchez-Mercado A, Ferrer-Paris JR, Yerena E, García-Rangel S, Rodríguez-Clark K (2008) Factors affecting poaching risk to vulnerable Andean bears Tremarctos ornatus in the Cordillera de Mérida, Venezuela: space, parks and people. Oryx 42:437-447

Steyaert S, Zedrosser A, Elfström M, Ordiz A, Leclerc M, Frank S, Kindberg J, Støen O-G, Brunberg S, Swenson JE (2016) Ecological implications from spatial patterns in human-caused brown bear mortality. Wildl Biol 22:144-152

Stillfried M, Belant JL, Svoboda NJ, Beyer DE, Kramer-Schadt S (2015) When top predators become prey: black bears alter movement behaviour in response to hunting pressure. Behav Process 120:30-39

Støen O-G, Ordiz A, Evans A, Laske TG, Kindberg J, Frobert O, Swenson JE, Arnemo J (2015) Physiological evidence for a humaninduced landscape of fear in brown bears (Ursus arctos). Physiol Behav 152:244-248

Sutherland WJ, Dicks LV, Ockendon N, Smith RK (2015) What works in conservation. Cambridge: Open Book Publishers, 2015. http:// dx.doi.org/10.11647/OBP.0060

Treves A (2009) Hunting for large carnivore conservation. J Appl Ecol 46:1350-1356

Trouwborst A (2015) Global large carnivore conservation and international law. Biodivers Conserv 24:1567-1588

Tuomainen U, Candolin U (2011) Behavioural responses to human induced environmental change. Biol Rev 86:640-657

Wam HK, Hjeljord O (2012) From overlooking to concealed: predator avoidance in an apex carnivore. Eur J Wildl Res 58:1001-1003

Williams DR, Pople RG, Showler DA, Dicks LV, Child MF, zu Ermgassen EK, Sutherland WJ (2013) Bird conservation: global evidence for the effects of interventions. Synopses of conservation evidence series. Pelagic Publishing, Exeter

Woodroffe R, Ginsberg JR (1998) Edge effects and the extinction of populations inside protected areas. Science 280:2126-2128

Woodroffe R, Thirgood S, Rabinowitz A (2005) People and wildlife, conflict or coexistence?. Cambridge University Press, Cambridge 